\title{
Liquefaction potential evaluation at Catania Harbour (Italy)
}

\author{
M. Maugeri \& S. Grasso \\ Department of Civil and Environmental Engineering, \\ University of Catania, Italy
}

\begin{abstract}
According to the frequency and the importance of the seismic effects suffered in past times, Eastern Sicily must be considered one of the highest seismic risk areas in Italy. The area to the south of Volcano Etna, on the east of the IbleoMaltese escarpment, known as Iblean Area, is therefore a seismogenic area. The harbour of the city of Catania, located on the eastern zone of Sicily, is an area subjected to high seismic hazards, as well as the whole city of Catania. The city of Catania in South-Eastern Sicily has been affected by several destructive earthquakes of about magnitude 7.0+ in past times; a repetition of events with similar characteristics would provide the additional risk of a damaging tsunami, as well as liquefaction phenomena around the coast.

In situ investigations of sandy harbour soil were carried out in order to determine the soil profile and the geotechnical characteristics for the site under consideration, with special attention paid for the variation of shear modulus and damping with depth. Seismic Dilatometer Marchetti Tests (SDMT) have also been carried out, with the aim of evaluating the soil profile of shear wave velocity (Vs), as well as the profile of the horizontal stress index $\mathrm{K}_{\mathrm{D}}$. Moreover, the following investigations in the laboratory were carried out on undisturbed samples: Resonant Column tests; Direct shear tests; and Triaxial tests. The available data obtained from the Seismic Dilatometer Marchetti Test results enabled us to evaluate the correct shear modulus profile. In addition, using some synthetic seismograms of historical scenario earthquakes at the bedrock, ground response analysis at the surface, in terms of time history and response spectra, has been performed by the 1-D non-linear code EERA. The results of the site response analyses have been used for the evaluation of liquefaction hazard of the investigated area.
\end{abstract}




\section{Introduction}

The coastal plain of the city of Catania, which is recognized as a typical Mediterranean city at high seismic risk, was investigated by SDMT. Seismic liquefaction phenomena were reported by historical sources following the 1693 $\left(\mathrm{Ms}=7.0-7.3, \mathrm{I}_{0}=\mathrm{X}-\mathrm{XI} \mathrm{MCS}\right)$ and $1818\left(\mathrm{Ms}=6.2, \mathrm{I}_{0}=\mathrm{IX} \mathrm{MCS}\right)$ Sicilian strong earthquakes [1-3] (Figure 1). The most significant liquefaction features seem to have occurred in the Catania area, situated in the meisoseismal region of both events. These effects are significant for the implications on hazard assessment mainly for the harbour of the city, where most facilities are located. The Val di Noto earthquake of January, 111693 is the best remembered by Sicilians. The shock of January 11 which developed from the epicentre (situated at sea but not far from the coast) measured XI on MCS $[5,6]$ (see figure 1). The life toll was enormous: estimates of victims vary from 11,000 (more probable) to 20,000 from a total of about 23-27,000 inhabitants. On the contrary, the Etna earthquake that took place on February 20, 1818 was one of the feeblest ever occurred but its effects were noticed over a vast area. This event as a whole shows that the quake reached the peak of IX on MCS [7] (see figure 1). The isoseismal map explains that the earthquake was perceived almost in every part of Sicily from Siracusa to Noto and Palermo. In order to study the dynamic characteristics of soils in the Catania harbour area, laboratory and in situ investigations have been carried out to obtain soil profiles with special attention being paid to the variation of the shear modulus $(\mathrm{G})$ and damping ratio (D) with depth. Seismic Dilatometer Marchetti Tests (SDMT) have been also carried out in the zone of the harbour area, with the aim of an accurate geotechnical characterisation, evaluating also the soil profile of shear wave velocity (Vs), as well as the profile of the horizontal stress index $\mathrm{K}_{\mathrm{D}}$. Moreover the following investigations in the laboratory were carried out on undisturbed samples: Resonant Column tests; Direct shear tests; Triaxial tests.

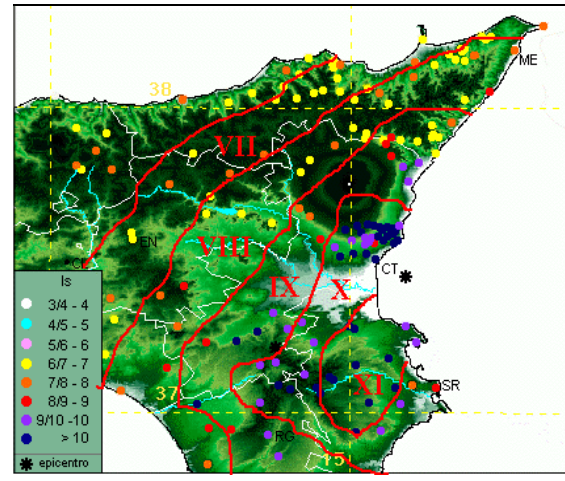

(a)



(b)

Figure 1: Isoseismal maps with shocked localities. (a) Earthquake of January 11, 1693; (b) Earthquake of February 20, 1818. After [4], modified. 


\section{Geotechnical characterisation by SDMT tests}

To evaluate the geotechnical characteristics of the soil, the following in situ and laboratory tests were performed in the Catania harbour area: $\mathrm{N}^{\circ} .5$ Seismic Dilatometer Tests (SDMT); $\mathrm{N}^{\circ} .3$ Direct Shear Tests; $\mathrm{N}^{\circ} .3$ Triaxial CD Tests; $\mathrm{N}^{\circ}$. 6 Resonant Column Tests (RCT). The investigation programme was performed in the zone of "Acquicella Porto" in the Catania harbour. The 5 Seismic Dilatometer Tests (SDMT1-5) have an effective depth of $30.50 \mathrm{~m}$, $32.00 \mathrm{~m}, 31.00 \mathrm{~m}, 30.00 \mathrm{~m}, 32.00 \mathrm{~m}$. Figure 1 shows the location of the SDMTs in the Catania harbour. The SDMT [8-10] provides a simple means for determining the initial elastic stiffness at very small strains and in situ shear strength parameters at high strains in natural soil deposits. Source waves are generated by striking a horizontal plank at the surface that is oriented parallel to the axis of a geophone connects by a co-axial cable with an oscilloscope [11, 12]. The measured arrival times at successive depths provide pseudo interval Vs profiles for horizontally polarized vertically propagating shear waves. The small strain shear modulus $\mathrm{G}_{0}$ is determined by the theory of elasticity by the well known relationships: $\mathrm{G}_{0}=\rho \mathrm{Vs}^{2}$ where: $\rho=$ mass density. SDMT obtained parameters are: $\mathrm{I}_{\mathrm{d}}$ : Material Index; gives information on soil type (sand, silt, clay), figure 3(a); M: Vertical Drained Constrained Modulus, figure 3(b); Phi: Angle of Shear Resistance, figure 4(a); $K_{D}$ : Horizontal Stress Index, figure 4(b) (the profile of $\mathrm{K}_{\mathrm{D}}$ is similar in shape to the profile of the overconsolidation ratio OCR. $\mathrm{K}_{\mathrm{D}}=2$ indicates in clays $\mathrm{OCR}=1, \mathrm{~K}_{\mathrm{D}}>2$ indicates overconsolidation. A first glance at the $\mathrm{K}_{\mathrm{D}}$ profile is helpful to "understand" the deposit); Vs: Shear Waves Velocity, figure 5(a); $\mathrm{G}_{0}=\rho \mathrm{Vs}^{2}$ Small Strain Shear Modulus, figure 5(b). The "Acquicella" site along the southern coast line of Catania is characterized by fine sands with thin limestone.



Figure 2: Location of the 5 SDMTs in the "Acquicella Porto" Catania harbour. 




(a)

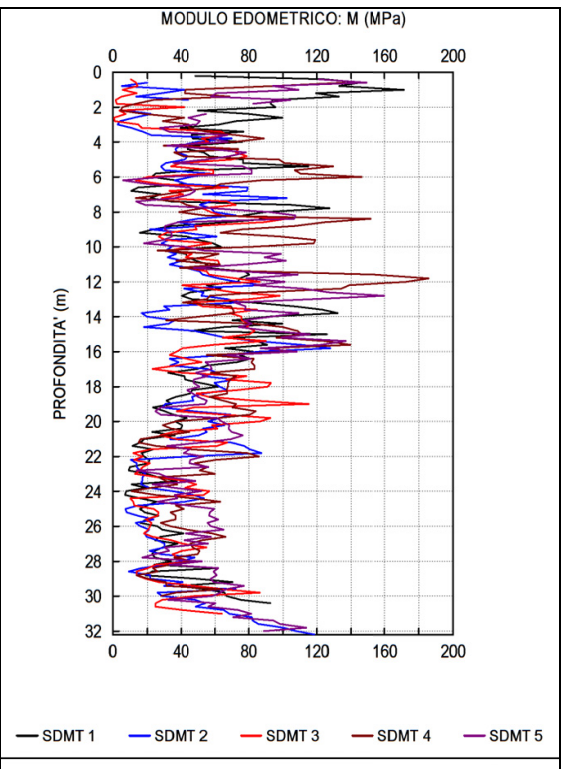

(b)

Figure 3: (a) $\mathrm{I}_{\mathrm{d}}$ : Material Index; (b) M: Vertical Drained Constrained Modulus.

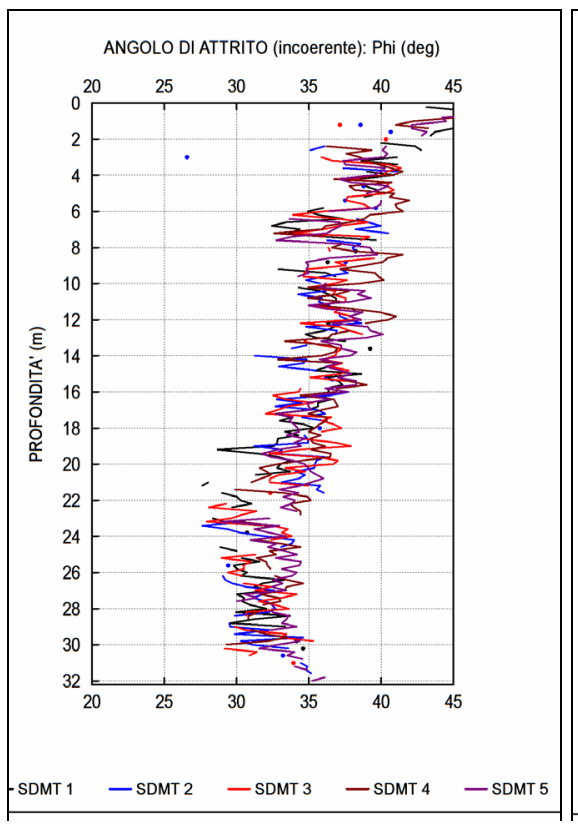

(a)

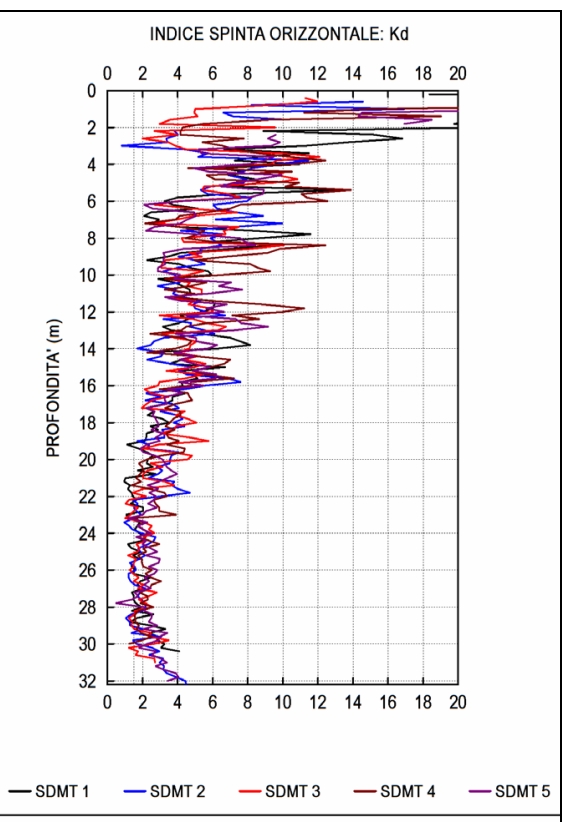

(b)

Figure 4: (a) Phi: Angle of Shear Resistance; (b) $\mathrm{K}_{\mathrm{D}}$ : Horizontal Stress Index. 


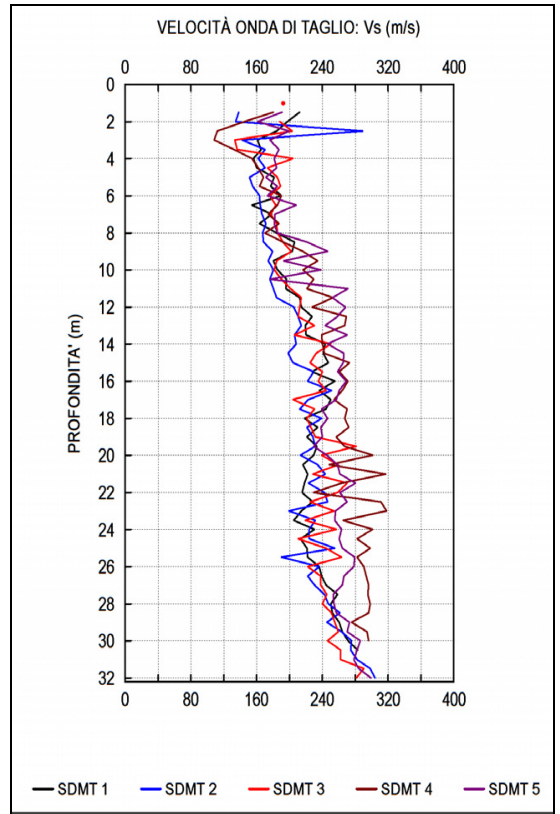

(a)



(b)

Figure 5: (a) Vs Shear Wave Velocity; (b) $\mathrm{G}_{0}$ : Small Strain Shear Modulus.

Figure 6 shows as an example the results of the Direct Shear Tests performed on the sample retrieved at the depth of $8.50 \mathrm{~m}$ from borehole SDMT3. Other two tests have been performed on samples retrieved from borehole SDMT1 at the depths of 13.20 and $39.00 \mathrm{~m}$. Results of the laboratory tests (Direct shear tests; Triaxial tests) performed on samples show that soils characterised are cohesionless, with values of the angle of shear resistance of about $37^{\circ}-38^{\circ}$.
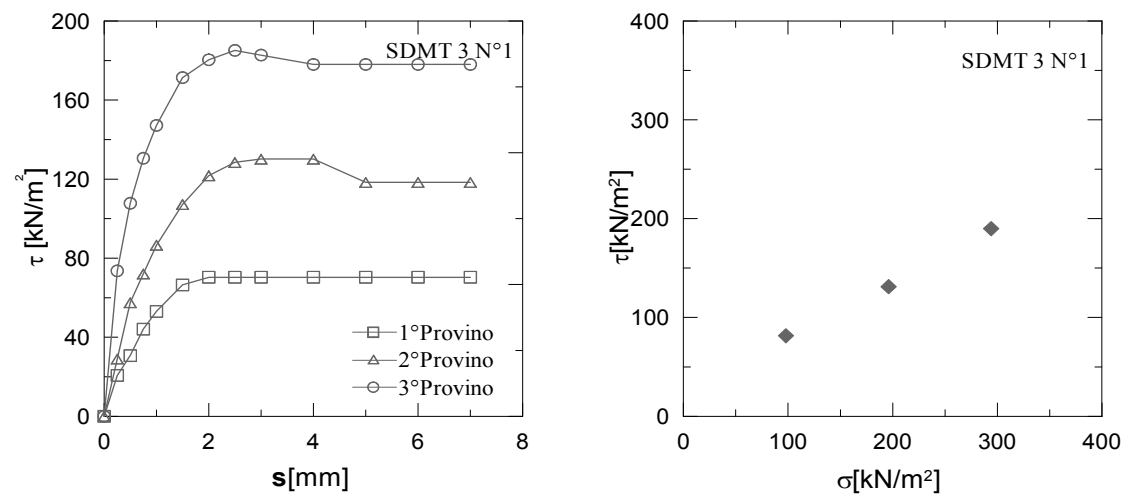

Figure 6: Results of the Direct Shear Test performed on the sample retrieved at the depth of $8.50 \mathrm{~m}$ from borehole SDMT3. 


\section{Seismic acceleration and evaluation of site effects}

Site response analysis, performed by EERA code [13], was carried out by all the normalized shear modulus and damping ratio reported. 1-D columns have a height of 30-32 $\mathrm{m}$ and are excited at the base by accelerograms obtained from the synthetic seismograms of 1693, with a PGA of $0.225 \mathrm{~g}$ (Figure 7(a)) corresponding to a return period of 475 years in the current Italian regulatory text "seismic hazard and seismic classification criteria for the national territory" obtained by a probabilistic approach in the interactive seismic hazard maps by $[14,15]$. Further analyses have been performed using scaled seismograms, to the maximum PGA of $0.275 \mathrm{~g}$ (corresponding to the return period of 975 years, Figure $7(\mathrm{~b})$ ) and to the maximum PGA of $0.400 \mathrm{~g}$ (corresponding to the return period of 2475 years, Figure 7(c)).

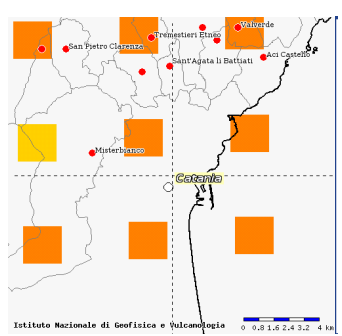

(a)

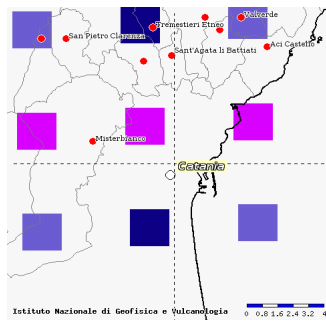

(b)



(c)

Figure 7: Interactive seismic hazard map of the city of Catania. (a) $10 \%$ probability of exceedance in 50 years (return period of 475 years); (b) $5 \%$ probability of exceedance in 50 years (return period of 975 years); (c) $2 \%$ probability of exceedance in 50 years (return period of 2475 years).

Using these time histories, response spectra concerning the investigated site have been deduced. The soil response at the surface was modeled using the Equivalent-linear Earthquake site Response Analyses of Layered Soil Deposits computer code EERA for calculus of amplitude ratios and spectral acceleration. Figure 8 show the results in terms of maximum accelerations with depth for SDMTs No. 1-5, respectively for the 475, 975 and 2475 return periods. Results of the site response analysis show high values of soil amplification factors especially for the 475 and for the 975 return periods of the scenario earthquake. Probably this fact is due to a non linear behaviour of soil that often occurs [16], especially in presence of the strong accelerations of the 975 and 2475 earthquake scenarios. High values of soil amplification factors often occur in the city of Catania due to the characteristics of soils, both stratigraphic and topographic [17-20]. The results of the site response analyses have been then used for the evaluation of liquefaction hazard of the investigated area, in terms of the maximum acceleration of the scenario earthquake chosen in the analyses. 




(a)



(b)

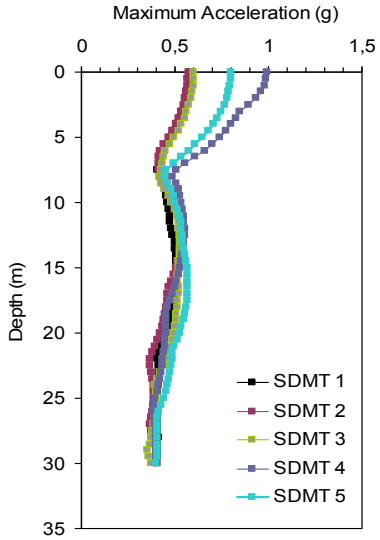

(c)

Figure 8: Maximum accelerations with depth for SDMTs No. 1-5 profiles. (a) 475 years earthquake scenario return period; (b) 975 years earthquake scenario return period; (c) 2475 years earthquake scenario return period.

\section{SDMT-based procedure for evaluating soil liquefaction}

Seismic liquefaction phenomena were reported by historical sources following the 1693 and 1818 earthquakes. The most significant liquefaction features seem to have occurred in the Catania area, situated in the meisoseismal region of both events. Extensive liquefaction effects occurred in the Catania area following the January 11, 1693 mainshock. Probably due to the severity of the earthquake $\left(\mathrm{M}_{\mathrm{s}}=7.0-7.3, \mathrm{I}_{\mathrm{o}}=\mathrm{X}-\mathrm{XI} \mathrm{MCS}\right)$, contemporary sources tended essentially to describe the catastrophic consequences of damage suffered by the towns, providing only generic information on seismogeological effects among which the liquefaction-induced features. Often during strong earthquakes, effects of liquefaction phenomena are visible also far from the epicentral area [21]. Previous studies performed in the industrial area of the city of Catania revealed a high liquefaction hazard during a possible repetition of the scenario earthquakes $[22,23]$.

\section{Cyclic shear Stress Ratios induced by earthquake ground motions}

The susceptibility of a site to seismic-induced liquefaction may be assessed comparing the cyclic soil resistance to the cyclic shear stresses due to the ground motion. The latter is of course a function of the design earthquake parameters, while the former depends on the soil shear strength and can be computed using results from in situ tests.

The traditional procedure, introduced by [20], has been applied for evaluating the liquefaction resistance of "Acquicella Porto" harbour sandy soils. This method requires the calculation of the cyclic stress ratio CSR, and cyclic resistance ratio $\mathrm{CRR}$. If $\mathrm{CSR}$ is greater than $\mathrm{CRR}$, liquefaction can occur. The cyclic stress ratio CSR is calculated by the following equation [24]: 


$$
\operatorname{CSR}=\tau_{\mathrm{av}} / \sigma^{\mathrm{v}}{ }_{\mathrm{vo}}=0.65\left(\mathrm{a}_{\max } / \mathrm{g}\right)\left(\sigma_{\mathrm{vo}} / \sigma^{\mathrm{v}}{ }_{\mathrm{vo}}\right) \mathrm{r}_{\mathrm{d}} / \mathrm{MSF}
$$

where $\tau_{a v}=$ average cyclic shear stress, $a_{\max }=$ peak horizontal acceleration at the ground surface generated by the earthquake, $g=$ acceleration of gravity, $\sigma_{v o}$ and $\sigma^{6}{ }_{v o}=$ total and effective overburden stresses, $r_{d}=$ stress reduction coefficient depending on depth and MSF is magnitude scaling factor. Seed and Idriss [24] introduced the stress reduction coefficient $r_{d}$ as a parameter describing the ratio of cyclic stresses for a flexible soil column to the cyclic stresses for a rigid soil column. As regards the peak horizontal acceleration, the value of $0.45 \mathrm{~g}$ has been chosen, It is the value of the acceleration with the $5 \%$ probability of exceedance in 50 years (return period of 975 years), amplified with an amplification factor of 1.80 given by the seismic response analysis. The magnitude scaling factor, MSF, has been used to adjust the induced CSR during earthquake magnitude $M$ $(\mathrm{M}=7.3$ of the 1693 scenario earthquake) to an equivalent CSR for an earthquake magnitude, $\mathrm{M}=7 \frac{1}{2}$. Figure 9 shows typical CSR profiles obtained i.e. for boreholes SDMT1-3.
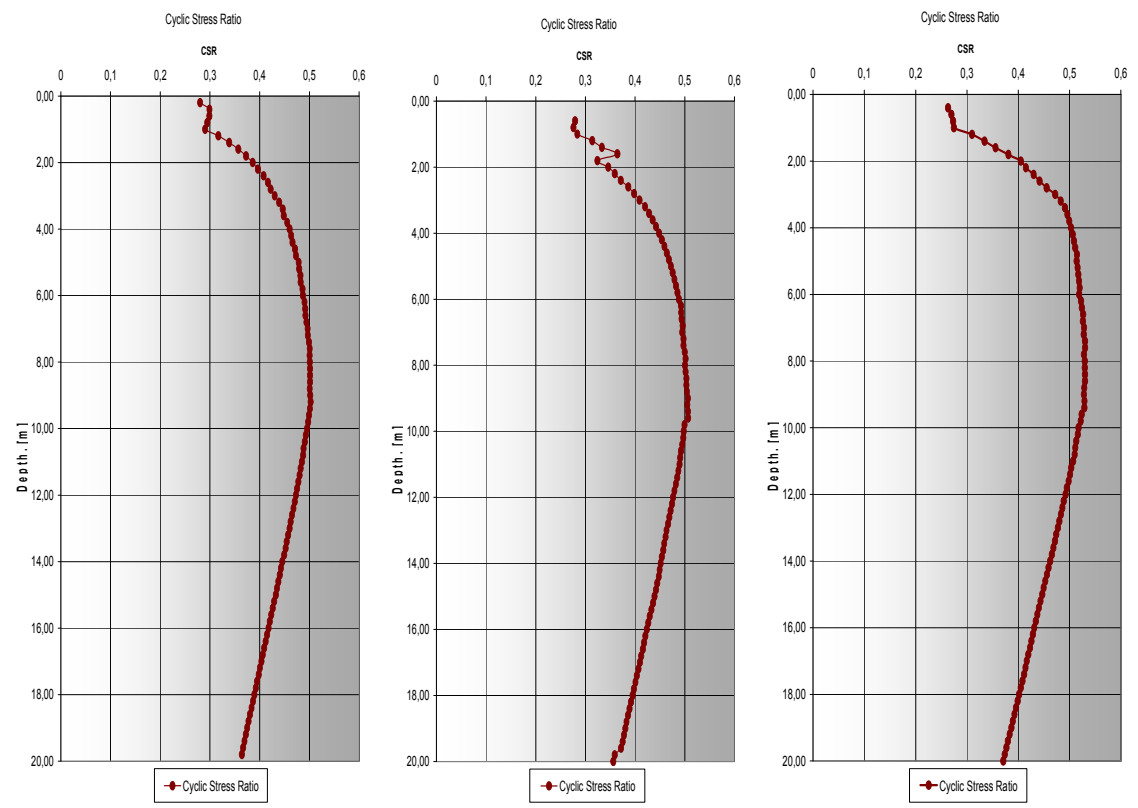

Figure 9: $\quad$ CSR profiles obtained from equation (1) for boreholes SDMT1-3.

Evaluation of CRR from the DMT horizontal stress index $\mathrm{K}_{\mathrm{D}}$

Marchetti [25] and later studies suggested that the horizontal stress index $\mathrm{K}_{\mathrm{D}}$ from DMT $\left(K_{D}=(p o-u o) / \sigma^{\prime} v o\right)$ is a suitable parameter to evaluate the liquefaction resistance of sands. Previous $C R R-K_{D}$ curves were formulated by Marchetti [25]. The following $C R R-K_{D}$ curves have been used in the present study, approximated by the equations:

$$
\mathrm{CRR}=0.0107 K_{D}{ }^{3}-0.0741 K_{D}{ }^{2}+0.2169 K_{D}-0.1306
$$




$$
\begin{gathered}
\mathrm{CRR}=0.0242 \mathrm{e}^{\left(0.6534 \mathrm{~K}_{\mathrm{D}}\right)} \\
\mathrm{CRR}=0.0084 K_{D}^{2.7032}
\end{gathered}
$$

Equation (2) has been developed by [26]; equations (3) and (4) have been developed by [23]. Figure 10 shows CRR- $K_{D}$ trends i.e. for SDMT1-2.


Figure 10: $\quad$ CRR- $K_{D}$ trends obtained used $K_{D}$ values from SDMT1-2.

\section{Evaluation of CRR from shear wave velocity Vs measured by SDMT}

The use of the shear wave velocity, $\mathrm{V}_{\mathrm{S}}$, as an index of liquefaction resistance has been illustrated by several authors $[27,28]$. The $\mathrm{V}_{\mathrm{S}}$ based procedure for evaluating CRR has advanced significantly in recent years. The correlations between $\mathrm{V}_{\mathrm{S}}$ and CRR used in the present study are given by Andrus and Stokoe [27] and Andrus et al. [28]:

$$
\begin{gathered}
\mathrm{CRR}=a\left(\frac{V_{S 1}}{100}\right)^{2}+b\left(\frac{1}{\left(V_{S 1}^{*}-V_{S 1}\right)}-\frac{1}{V_{S 1}^{*}}\right) \\
\mathrm{CRR}=\left[0.022\left(\frac{K_{a 1} V_{S 1}}{100}\right)^{2}+2.8\left(\frac{1}{V_{S 1}^{*}-\left(K_{a 1} V_{S 1}\right)}-\frac{1}{V_{S 1}^{*}}\right)\right] K_{a 2}
\end{gathered}
$$

where $\mathrm{V}^{*}{ }_{\mathrm{s} 1}=$ limiting upper value of $\mathrm{V}_{\mathrm{s} 1}$ for liquefaction occurrence; $\mathrm{V}_{\mathrm{S} 1}=\mathrm{V}_{\mathrm{S}}$ $\left(\mathrm{p}_{\mathrm{a}} / \sigma^{\prime}{ }_{\mathrm{vo}}\right)^{0.25}$ is corrected shear wave velocity for overburden-stress; $\mathrm{a}$ and $\mathrm{b}$ of equation (5) are curve fitting parameters, while $K_{a 1}$ and $K_{a 2}$ are aging factors = 1.0 for uncemented soils of Holocene age. The correlations given by equations (2)-(6) have been then used for the evaluation of liquefaction potential index, $\mathrm{P}_{\mathrm{L}}$, (Iwasaki et al. [29]), using the $\mathrm{K}_{\mathrm{D}}$ and Vs values measured by SDMT instead. Figures 11-12 show $\mathrm{P}_{\mathrm{L}}$ values obtained respectively from $C R R-\mathrm{K}_{\mathrm{D}}$ and CRR-Vs correlations i.e. for SDMT1-2.

However the CRR-Vs correlations are not reliable when Vs exceeds the value of $225 \mathrm{~m} / \mathrm{s}$. In addition, the $\mathrm{V}_{\mathrm{s}}$ measurements are made at small strains, whereas pore-pressure build up and liquefaction are medium- to high-strain phenomena. Thus, it could be preferable to evaluate liquefaction by $\mathrm{K}_{\mathrm{D}}$ measurements which is related to medium-high strains [30-32]. 

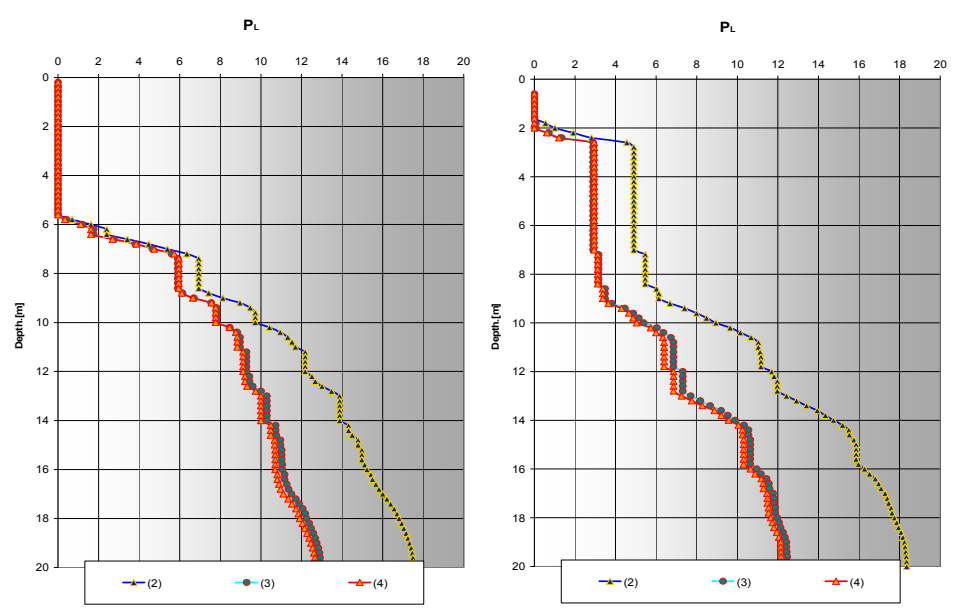

Figure 11: Liquefaction potential index $\mathrm{P}_{\mathrm{L}}$ obtained from CRR-K $\mathrm{K}_{\mathrm{D}}$ correlations.
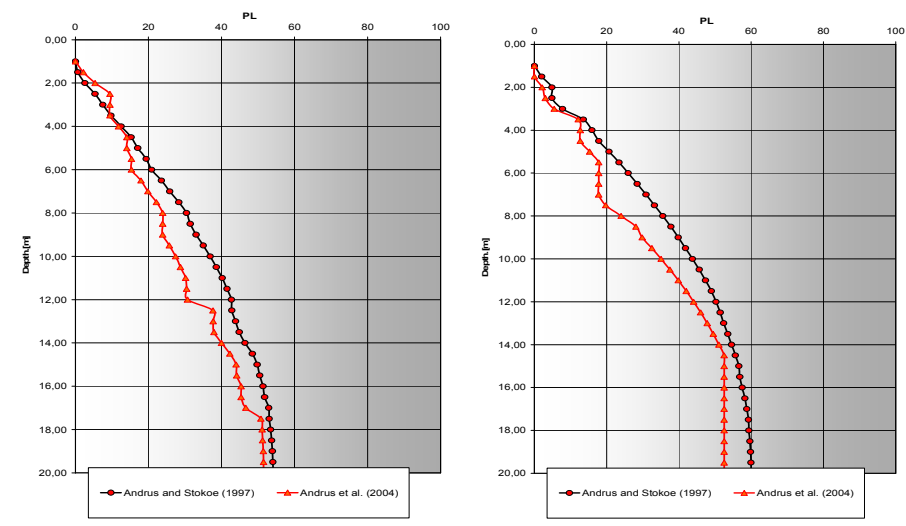

Figure 12: Liquefaction potential index $\mathrm{P}_{\mathrm{L}}$ obtained from CRR-Vs correlations.

\section{Conclusions}

In this paper some information concerning the geotechnical characterisation by SDMT tests for soil liquefaction evaluation of the "Acquicella Porto" zone in the Catania harbour (Italy) have been presented. Local site response analyses have been brought for the "Acquicella Porto" area by a 1-D linear equivalent computer code EERA for the evaluation of the amplification factors of the maximum acceleration [33-37]. CRR- $K_{D}$ correlations have been used for the evaluation of liquefaction potential index, $\mathrm{P}_{\mathrm{L}}$. The results obtained is SDMT1 show that the Liquefaction Potential Index $\mathrm{P}_{\mathrm{L}}$ is below 5 (low risk) up to a depth of about 7 meters; while the results obtained by SDMT2 show low risk up to a depth of $10 \mathrm{~m}$. By the way, it is unlikely to have liquefaction at a depth greater than $7-10 \mathrm{~m}$. 


\section{References}

[1] Grasso, S., Maugeri, M. (2009). The Road Map for Seismic Risk Analysis in a Mediterranean City. Soil Dynamics and Earthquake Engineering. ISSN: 0267-7261. 29 (6), 2009: 1034-1045.

[2] Grasso, S., Maugeri, M. (2009). The Seismic Microzonation of the City of Catania (Italy) for the Maximum Expected Scenario Earthquake of January 11, 1693, Soil Dynamics and Earthquake Engineering, 29 (6), 2009: 953-962.

[3] Grasso S., Maugeri M. (2012). The Seismic Microzonation of the City of Catania (Italy) for the Etna Scenario Earthquake $(M=6.2)$ of February 20, 1818. Earthquake Spectra. Vol. 28 (2), May 2012, 573-594. ISSN: 87552930.

[4] Monachesi, G. and Stucchi, M. (eds), (2000). DOM4.1: an intensity database of damaging earthquakes in the Italian area, GNDT-CNR open file report, 2 vv., Milano. Website: http://emidius.mi.ingv.it/DOM/.

[5] Barbano, M.S. (1985). The Val di Noto earthquake of January 11, 1693. In: Postpischl, D. (ed.), Atlas of Isoseismal Maps of Italian Earthquakes, PFG-CNR, Quad. Ric. Scie. 2A, 114, Bologna, 48-49.

[6] Ligresti D., Grasso S. (2009). Historical View of the Damage caused by the 1693 Catania Earthquake and the Reconstruction Activities. In: Proc. 1st Int. Conf. on Disaster Management and Human Health. New Forest, UK, September 23-25, 2009, 323-331, South: WIT Press, ISBN: 978-184564-202-0

[7] Imposa, S., Lombardo, G. (1985). The Etna earthquake of February 20, 1818. In: Postpischl, D. (ed), Atlas of Isoseismal Maps of Italian Earthquakes, PFG-CNR, Quad. Ric. Scie. 2A, 114, Bologna, 80-81.

[8] Marchetti, S. (1980). In Situ Tests by Flat Dilatometer. Journal of the Geotechnical Engineering Division, ASCE, Vol. 106, N. GT3, March, 1980, 299-321.

[9] Marchetti S., Monaco P., Totani G., Marchetti D. (2008). In Situ Tests by Seismic Dilatometer (SDMT). In: "From Research to Practice in Geotechnical Engineering”, ASCE Geotech. Spec. Publ. No. 180 Honouring John H. Schmertmann, 292-311.

[10] Monaco P., Marchetti S., Totani G., Marchetti D. (2009). Interrelationship between Small Strain Modulus Go and Operative Modulus. In: Kokusho, Tsukamoto and Yoshimine (eds), Proc. Int. Conf. on Performance-Based Design in Earthquake Geotechnical Engineering (IS-Tokyo 2009), Tsukuba, Japan, June 15-17, 1315-1323. Taylor \& Francis Group, London.

[11] Martin, G.K. and Mayne, P.W. (1997). Seismic Flat Dilatometer Tests in Connecticut Valley Varved Clay. ASTM Geotech. Testing J., 20(3), 357361.

[12] Martin, G.K. and Mayne, P.W. (1998). Seismic Flat Dilatometer in Piedmont Residual Soils. In P.K. Robertson and P.W. Mayne (eds), Proc. 1st Int. Conf. on Site Charact., Atlanta, 2, 837-843. Rotterdam: Balkema.

[13] EERA (2000). http://gees.usc.edu/GEES/Software/EERA2000/Default.htm 
[14] Meletti C., Montaldo V. (2007). Stime di pericolosità sismica per diverse probabilità di superamento in 50 anni: valori di ag. Progetto DPC-INGV S1, Deliverable D2, http://esse1.mi.ingv.it/d2.html

[15] Meletti C., Galadini F., Valensise G., Stucchi M., Basili R., Barba S., Vannucci G., Boschi E. (2008). A seismic source model for the seismic hazard assessment of the Italian territory. Tectonophysics 450, 85-108.

[16] Maugeri M., Simonelli A.L., Ferraro A., Grasso S., Penna A. (2011). Recorded ground motion and site effects evaluation for the April 6, 2009 L'Aquila earthquake. Bull Earthquake Eng (2011) 9, pp.157-179. doi 10.1007/s10518-010-9239-x. ISSN: 1570-761X (print version), ISSN: 1573-1456 (electronic version).

[17] Cavallaro, A., Ferraro, A., Grasso, S., Maugeri, M. (2012). Topographic effects of the Monte Po hill in Catania (Italy). Soil Dynamics and Earthquake Engineering. ISSN: 0267-7261. Vol. 43 (2012): 97-113.

[18] Ferraro A., Grasso S., Maugeri M. (2009). Seismic Vulnerability of a slope in Central Italy. In: Proc. First International Conference on Disaster Management and Human Health. New Forest, UK, September 23-25, 2009, 345-356, Southampton: WIT Press, ISBN: 978-1-84564-202-0

[19] Grasso S., Maugeri M. (2009). The Road Map for the Seismic Geotechnical Vulnerability of Physical Environment. In: Proc. 1st Int. Conf. on Disaster Management and Human Health. New Forest, UK, Sep. 23-25, 2009, 333-344, Southampton: WIT Press, ISBN: 978-1-84564-2020

[20] Cavallaro A., Ferraro A., Grasso S., Maugeri M. (2008). Site Response Analysis of the Monte Po Hill in the City of Catania. In: 2008 Seismic Engineering Conference Commemorating the 1908 Messina and Reggio Calabria Earthquake. Messina and Reggio Calabria, July 8-11, 2008, 240251, ISBN: 978-0-7354-0542-4.

[21] Monaco P., Santucci De Magistris F., Grasso S., Marchetti S., Maugeri M., Totani G. (2011). Analysis of the liquefaction phenomena in the village of Vittorito (L'Aquila). Bull Earthquake Eng (2011) 9, 231-261. doi 10.1007/s10518-010-9228-0. ISSN: 1570-761X (print version), ISSN: 1573-1456 (electronic version).

[22] Grasso S., Maugeri M., Monaco P. (2006). Using Kd and Vs from Seismic Dilatometer (SDMT) for Evaluating Soil Liquefaction. Proc. of 2nd Int. Conf. on the Flat Dilatometer, Washington, April 2-5, 2006.

[23] Grasso S., Maugeri M. (2008). The Seismic Dilatometer Marchetti Test (SDMT) for Evaluating Liquefaction Potential under Cyclic Loading. Proc. IV Geotechnical Earthquake Engineering and Soil Dynamics. Sacramento, USA, May 18-22, 2008. Geotechnical Earthquake Engineering and Soil Dynamics IV GSP 181 C 2008 ASCE, Geo Institute, ISBN 978-0-7844-0975-6, $15 \mathrm{p}$.

[24] Seed, H.B. \& Idriss, I.M. (1971). Simplified procedure for evaluating soil liquefaction potential. Jnl GED, ASCE, 97(9), 1249-1273. 
[25] Marchetti, S. (1982). Detection of liquefiable sand layers by means of quasi-static penetration tests. Proc. 2nd European Symp. on Penetration Testing, Amsterdam, 2, 689-695.

[26] Monaco, P., Marchetti, S., Totani, G. \& Calabrese, M. (2005). Sand liquefiability assessment by Flat Dilatometer Test (DMT). Proc. XVI ICSMGE, Osaka, 4, 2693-2697.

[27] Andrus, R.D. \& Stokoe, K.H., II. (2000). Liquefaction resistance of soils from shear-wave velocity. Jnl GGE, ASCE, 126(11), 1015-1025.

[28] Andrus, R.D., Stokoe, K.H., II, \& Juang, C.H. (2004). Guide for ShearWave-Based Liquefaction Potential Evaluation. Earthquake Spectra, 20(2), 285-305.

[29] Iwasaki, T., Tatsuoka, F., Tokida, K. \& Yasuda, S. (1978). A practical method for assessing soil liquefaction potential based on case studies at various sites in Japan. Proc 2nd Int. Conf on Microzonation for Safer Construction, Research and Application, S.F., California, 2, 885-896.

[30] Maugeri M., Monaco P. (2006). Liquefaction Potential Evaluation by SDMT. Proc. of 2nd Int. Conf. on the Flat Dilatometer, Washington, April 2-5, 2006.

[31] Cavallaro A, Grasso S, Maugeri M, Motta E. (2012). An innovative lowcost SDMT marine investigation for the evaluation of the liquefaction potential in the Genova harbour, Italy. In: Coutinho \& Mayne (eds) Taylor \& Francis Group. Int. Conf. on Geotechnical and Geophysical Site Characterization 4. Porto de Galinhas, Pernambuco Brazil, 18/09/2012, 637-644. , ISBN: 9780415621366

[32] Cavallaro A., Grasso S., Maugeri M., Motta E. (2012). Site characterisation by in situ and laboratory tests of the sea bed in the Genova Harbour, Italy. In: Coutinho \& Mayne (eds Taylor \& Francis Group, London. Int. Conf. on Geotechnical and Geophysical Site Characterization 4. Porto de Galinhas, Pernambuco Brazil, 18/09/2012, 415-422, ISBN: 9780415621366.

[33] Maugeri M., Totani G., Monaco P., Grasso S. (2011). Seismic Action to Withstand The Structures: The Case History of 2009 Abruzzo Earthquake. In: Proc. of 8th Int. Conf. on Earthquake Resistant Engineering Structures. Chianciano Terme, Sept. 7-9, 2011, 3-14, ISBN: 978-1-84564-548-9

[34] Monaco P., Totani G., Totani F., Grasso S., Maugeri M. (2011). Site Effects and Site Amplification due to the 2009 Abruzzo Earthquake. In: Proc. of 8th Int. Conf. on Earthquake Resistant Engineering Structures. Chianciano Terme, Sep. 7-9, 2011, 29-40, ISBN: 978-1-84564-548-9

[35] Cavallaro A., Grasso S., Maugeri M. (2008). Site Response Analysis for Tito Scalo Area (PZ) in the Basilicata Region. In: ASCE, Geo Institute. Geotechnical Special Publication No. 181 Geotechnical Earthquake Engineering and Soil Dynamics IV GSP 181. vol. 181, ASCE, American Society of Civil Engineers, ISBN: 978-0-7844-0975-6

[36] Maugeri M., Grasso S. (2007). A Road Map for Seismic Prevention of Damage. In: Proc. of 6th Int Conf. on Earthquake Resistant Engineering Structures. Bologna, Italy, 11-13 June 2007, Southampton: WIT Press. 
82 Earthquake Resistant Engineering Structures IX

[37] Condarelli D., Grasso S., Maugeri M., Langer H., Pitilakis K., Manakou M. (2009). A methodology to design bedrock input motion using noise measurements. In: Proc. 17th Int. Conf. on Soil Mechanics and Geotechnical Engineering. Alexandria, Egypt, 5-9 October, 2009, 945948, ISBN: 978-1-60750-031-5, doi: 10.3233/978-1-60750-031-5-945 